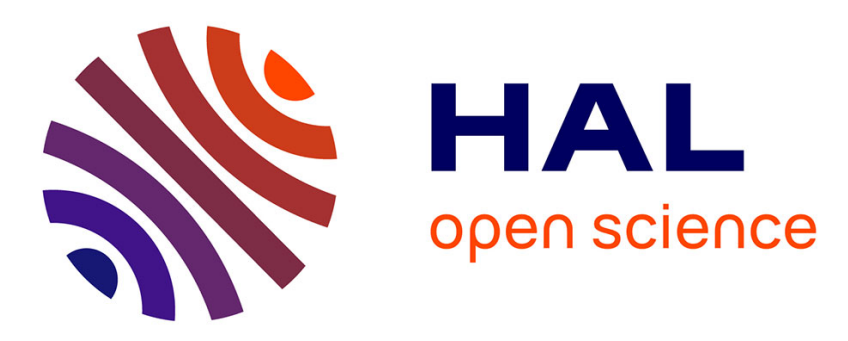

\title{
Mechanisms of folate losses during processing: Diffusion vs. heat degradation
}

\author{
Nicolas Delchier, Christiane Ringling, Jean Francois Maingonnat, Michael \\ Rychlik, Catherine Renard
}

\section{- To cite this version:}

Nicolas Delchier, Christiane Ringling, Jean Francois Maingonnat, Michael Rychlik, Catherine Renard. Mechanisms of folate losses during processing: Diffusion vs. heat degradation. Food Chemistry, 2014, 157, pp.439-447. 10.1016/j.foodchem.2014.02.054 . hal-01628093

\section{HAL Id: hal-01628093 https://hal.science/hal-01628093}

Submitted on 27 May 2020

HAL is a multi-disciplinary open access archive for the deposit and dissemination of scientific research documents, whether they are published or not. The documents may come from teaching and research institutions in France or abroad, or from public or private research centers.
L'archive ouverte pluridisciplinaire HAL, est destinée au dépôt et à la diffusion de documents scientifiques de niveau recherche, publiés ou non, émanant des établissements d'enseignement et de recherche français ou étrangers, des laboratoires publics ou privés. 


\title{
Mechanisms of folate losses during processing: Diffusion $v s$. heat degradation
}

\author{
Nicolas Delchier ${ }^{\mathrm{a}, \mathrm{b}, *}$, Christiane Ringling ${ }^{\mathrm{c}}$, Jean-François Maingonnat ${ }^{\mathrm{a}, \mathrm{b}}$, Michael Rychlik ${ }^{\mathrm{c}, \mathrm{d}}$, \\ Catherine M.G.C. Renard ${ }^{\mathrm{a}, \mathrm{b}, *}$ \\ a INRA, UMR408 Sécurité et Qualité des Produits d'Origine Végétale, Domaine Saint Paul, Site Agroparc, F-84000 Avignon, France \\ ${ }^{\mathrm{b}}$ Université d'Avignon et des Pays du Vaucluse, UMR408 Sécurité et Qualité des Produits d'Origine Végétale, F-84000 Avignon, France \\ ' Bioanalytik Weihenstephan, Research Center of Nutrition and Food Sciences, Technische Universität München, Alte Akademie 10, D-85354 Freising, Germany \\ ${ }^{\mathrm{d}}$ Chair of Analytical Food Chemistry, Technische Universität München, Alte Akademie 10, D-85354 Freising, Germany
}

Keywords:

Vitamins

Folate

Vegetables

Process

Leaching

Heat degradation

Kinetics

Fick's second law

\begin{abstract}
A B S T R A C T
Though folates are sensitive to heat treatments, leaching appears to be a major mechanism involved in folate losses in vegetables during processing. The aim of our study was to study folate diffusivity and degradation from spinach and green beans, in order to determine the proportion of each mechanism involved in folate losses.

Folate diffusivity constant, calculated according to Fick's second law (Crank, 1975), was $7.4 \times 10^{-12} \mathrm{~m}^{2} / \mathrm{s}$ for spinach and $5.8 \times 10^{-10} \mathrm{~m}^{2} / \mathrm{s}$ for green beans, which is the same order of magnitude as for sugars and acids for each vegetable considered. Folate thermal degradation kinetics was not monotonous in spinach and green beans especially at $45^{\circ} \mathrm{C}$ and did not follow a first order reaction. The proportion of vitamers changed markedly after thermal treatment, with a better retention of formyl derivatives. For spinach, folate losses were mainly due to diffusion while for green beans thermal degradation seemed to be preponderant.
\end{abstract}

\section{Introduction}

Folate is the generic term used for different water-soluble vitamers which differ by the nature of carbon groups linked to nitrogen 5 or 10 , the oxidative state and the length of the glutamate tail. They are involved in the "one carbon metabolism" especially being donor of methyl group during DNA synthesis. It is well established that folates can protect against neural tube defects (Czeizel \& Dudás, 1992) and neurodegenerative diseases (Snowdon, Tully, Smith, Riley, \& Markesbery, 2000). Folates are also involved in the methylation of homocysteine, which is one risk factor for heart diseases (Robinson, 2000).

One of the main contributors for folate intake are vegetables, and particularly green vegetables, which represent circa $40 \%$ of the folate intake in the French diet (Lafay, 2009). In France, authorities recommend an intake of folate from $300 \mu \mathrm{g}$ per day for women to $330 \mu \mathrm{g}$ per day for men, with an increase to $1 \mathrm{mg}$ per

* Corresponding authors at: INRA, UMR408 Sécurité et Qualité des Produits d'Origine Végétale, Domaine Saint Paul, Site Agroparc, F-84000 Avignon, France. Tel.: +33 (0) 4327225 28; fax: +33 (0) 432722492 .

E-mail address: nicolas.delchier@gmail.com (N. Delchier). day during pregnancy (ANSES, 2012). However, there is a gap between the real and the recommended intake from around $20 \%$ for women to $15 \%$ for men (Lafay, 2009).

Evolution of lifestyles means that most fruits and vegetables are consumed after processing, whether domestic processing (cooking, heating, microwaves) or industrial processing, such as canning or freezing, hence there is a need to better understand the impact of processing on folate content.

Folate losses from spinach during boiling or blanching represent $20-80 \%$ of initial folates and from $0 \%$ to $20 \%$ in green beans (Delchier, Reich, \& Renard, 2012; Desouza \& Eitenmiller, 1986; Klein, Lee, Reynolds, \& Wangles, 1979; McKillop et al., 2002; Melse-Boonstra et al., 2002). However, steaming and microwave cooking did not cause folate losses (Delchier et al., 2012; Klein et al., 1979; McKillop et al., 2002). Few studies measured folates in cooking liquids but Delchier et al. (2012) showed that leached folates represent half of folate losses from fresh spinach and the whole of folates losses from frozen spinach and green beans, after boiling in water. Data concerning the impact of industrial processing on folate losses is really scarce. Our previous study showed that blanching had no effect on folate loss both during the spinach freezing process and the green beans canning process. Losses occur 
Version définitive du manuscrit publiée dans / Final version of the manuscript published in :

Food Chemistry (2014),vol 157, p 439-447, DOI: 10.1016/j.foodchem.2014..02.054

Journal homepage: www.elsevier.com/locate/foodchem

during the washing step for spinach and after sterilization for green beans, with folate found in the covering liquid (Delchier et al., 2013).

This study on folate loss during industrial processing led us to suspect that diffusion may play a major role in folate loss, especially when heating steps are limited.

Therefore, this study aims to determine the relative importance of diffusion and thermal degradation of spinach and green beans during heat treatments. For this, two parallel experiments were set up: one in which vegetables were only subjected to heat, and one in which they were subjected to heat and diffusion.

\section{Materials and methods}

\subsection{Plant material}

\subsubsection{Diffusion}

Fresh spinach and green beans were bought at a local supermarket on the day of the experiments, or stored at $4{ }^{\circ} \mathrm{C}$ for maximum of $48 \mathrm{~h}$ after purchase. Spinach and green beans were first blanched in phosphate buffer $\mathrm{pH} 7(0.01 \mathrm{~mol} / \mathrm{l})$ or in citrate phosphate buffer $\mathrm{pH} 5(0.01 \mathrm{~mol} / \mathrm{l})$ for $10 \mathrm{~min}$ at $100{ }^{\circ} \mathrm{C}$ with solid-liquid ratio of 50 and $100 \mathrm{~g} / \mathrm{l}$, respectively, in order to inactivate enzymes and destroy cell compartmentalization. After blanching, spinach and green beans were drained, weighted and immediately put into a large receptacle (with the same solid-liquid ratio of $50 \mathrm{~g} / \mathrm{l}$ ), to start the diffusion.

\subsubsection{Thermal degradation}

Purees were prepared from spinach and green beans stored in cans bought at local supermarket in two batches for each temperature condition. Cans were opened and vegetables were drained. $200 \mathrm{~g}$ of vegetables were put into $400 \mathrm{ml}$ of water and ground with an UltraTurax (S25 18G, IKA, Staufen, Germany) at 13,000 rpm for $1 \mathrm{~min}$. Spinach purees were diluted, to facilitate stirring during the time course. For this purpose, $50 \mathrm{ml}$ of water was added to $50 \mathrm{ml}$ of spinach puree.

\subsection{Time course experiments}

\subsubsection{Diffusion}

Diffusions experiments were carried out in phosphate buffer $\mathrm{pH}$ $7(0.01 \mathrm{~mol} / \mathrm{l})$ or citrate phosphate buffer pH $5(0.01 \mathrm{~mol} / \mathrm{l})$, under stirring. Temperature and $\mathrm{pH}$ were monitored and controlled all along the time course, which were performed for three temperatures $\left(25,45\right.$ and $\left.65{ }^{\circ} \mathrm{C}\right)$ and at $\mathrm{pH} 5$ and $\mathrm{pH} 7$ for $4 \mathrm{~h}$. At pH 7, three batches of spinach and green beans were independently studied and two batches at $\mathrm{pH} 5$.

For each kinetic point, an aliquot of $35 \mathrm{~g}$ of spinach or green beans was collected and directly stabilized by freezing in liquid nitrogen, and stored at $-80^{\circ} \mathrm{C}$ until analysis. The folate content was determined in the vegetables at each point along the time course.

\subsubsection{Thermal degradation}

Heat degradation was carried out in a beaker immersed in a water bath. Purees were stirred all along the experiments by a propeller stirrer of $55 \mathrm{~mm}$ diameter turning at $600 \mathrm{rpm}$ (VOS 16, VWR, Fontenay sous bois, France). Time courses were performed in two independent batches for three temperatures: 45,65 and $85^{\circ} \mathrm{C}$. Purees were heated and kinetics started when they were at the desired temperature. $10 \mathrm{ml}$ of puree were sampled at different points for $4 \mathrm{~h}$ and directly put at $-80^{\circ} \mathrm{C}$.

\subsection{Modelling}

\subsubsection{Diffusion}

Diffusivity constant $(D)$ was calculated for folates, sugars and acids according to Fick's second law Eq. (1):

$\frac{\partial C}{\partial t}=-D \frac{\partial^{2} C}{\partial r^{2}}$

where $C$ represents the concentration, $t$ the time and $r$ a characteristic distance.

Spinach leaves were considered as a plane sheet where Fick's second law solution, given by Crank (1975), is Eq. (2):

$$
\frac{C(t)-C_{\infty}}{C_{0}-C_{\infty}}=1-\sum_{n=0}^{\infty} \frac{8}{(2 n+1)^{2} \pi^{2}} \exp \left(-\frac{D(2 n+1)^{2} \pi^{2} t}{4 l^{2}}\right)
$$

where $C(t)$ is the concentration at time $t, C_{0}$ is the initial concentration and $C_{\infty}$ the concentration at infinite time, $D$ the diffusivity constant and $l$ the half thickness of the plane.

In the case of green beans, the diffusivity constant was determined according to the cylinder solution given by Crank (1975) Eq. (3):

$\frac{C(t)-C_{\infty}}{C_{0}-C_{\infty}}=1-\sum_{n=1}^{\infty} \frac{4}{a^{2} \alpha_{n}^{2}} \exp \left(-D \alpha_{n}^{2} t\right)$

where $C(t)$ is the folates concentration at $t$ time, $C_{0}$ is the initial concentration and $C_{\infty}$ the concentration at infinite time, $D$ the diffusivity constant and $a$ the radius. In this equation $\alpha_{n}$ is the root of Bessel function of order 0 Eq. (4).

$J_{0}\left(a \alpha_{n}\right)=0$

The model was adjusted by maximizing the correlation coefficient, $r^{2}$, calculated as follow Eq. (5):

$r^{2}=1-\left(\frac{\sum(\operatorname{Exp}-T h)^{2}}{\sum\left(\operatorname{Exp}-m_{T h}\right)^{2}}\right)$

where Exp is the experimental concentration; Th is the theoretical data obtained by modelling, and $m_{T h}$ is the mean of theoretical data obtained by modelling.

\subsubsection{Thermal degradation}

Linearization of folate thermal degradation was carried out according to the mean of the two batches for each temperature studied, using a first order with partial conversion model, as described below Eq. (6):

$\ln \left(\frac{C}{C_{0}}\right)=-k t$

where $C$ is the folate concentration, $C_{0}$ is the initial folate concentration, $k$ is the degradation rate constant and $t$ the time.

\subsection{Analytical procedures}

\subsubsection{Folate measurement}

2.4.1.1. Total folates content. Total folate content was determined by HPLC with fluorimetric detection. After extraction all folate vitamers were deconjugated into mono and diglutamate, reduced and methylated into $5-\mathrm{CH}_{3}-\mathrm{H}_{4}$ folates. The latter were purified from the extract by affinity chromatography using Folate Binding Protein, and quantified by RP-HPLC with fluorimetric detection (RF-1AXL, Shimadzu Inc., Kyoto, Japan). For experimental details, see Delchier et al. (2013).

2.4.1.2. Stable isotope dilution assay. Before extraction, labelled standards of folate vitamers were added and all folates were 
deconjugated into their monoglutamate forms. Vitamers were purified on SPE SAX cartridges after adding acetonitrile $(10 \mathrm{ml})$ and centrifugation. Folate analysis was carried out on an HPLC (Shimadzu Inc., Kyoto, Japan) coupled with a triple quadrupole mass spectrometer (API 4000 Q-Trap, AB-Sciex, Foster City, CA, USA). A Pro-C18 HPLC-column $(150 \times 3,3 \mu \mathrm{m}, 130 \AA$, YMC, Japan $)$ with water plus $0.1 \%(\mathrm{v} / \mathrm{v})$ formic acid $(\mathrm{A})$ and acetonitrile plus $0.1 \%$ $(\mathrm{v} / \mathrm{v})$ formic acid (B) as mobile phases was used. The gradient started at $5 \%$ B. After a linear increase to $10 \%$ B in 5 min and holding this condition for $5 \mathrm{~min}$, another linear increase to 15\% B during $10 \mathrm{~min}$ and to $50 \% \mathrm{~B}$ in $2 \mathrm{~min}$, which was maintained for $2 \mathrm{~min}$. Within 2 min B was decreased linearly to 5\% and the column was equilibrated for $9 \mathrm{~min}$.

Concentration of the single vitamers in the food samples was calculated using the response factors reported recently (Ringling \& Rychlik, 2013). For more experimental details see Ringling and Rychlik (2013).

\subsubsection{Acid and sugar measurement}

Acid and sugar concentrations were determined by spectrophotometry (Xenius, Safas, Monaco) by determining concentrations of NADPH and NADH respectively, at $340 \mathrm{~nm}$ using enzymatic kits. Enzymatic kits for citric acid (reference: 10.139.076), malic acid (reference: 10.139.068), glucose (reference: 10.716.251), fructose (reference: 10.139.106) and sucrose (reference: 10.716.251) were obtained from R-Biopharm (Darmstadt, Germany).

Sugars and acids were extracted from $200 \mathrm{mg}$ of spinach or green bean powder, to which $1 \mathrm{ml}$ of deionised water was added. The mix was stirred for $1 \mathrm{~min}$ and then centrifuged (Bioblock Scientific $1 \mathrm{~K} 15$, Illkirch, France) for $10 \mathrm{~min}$ at $7400 \mathrm{~g}$ at $4{ }^{\circ} \mathrm{C} .5 \mu \mathrm{l}$ of supernatant was pipetted into the microplate, and $250 \mu \mathrm{l}$ of enzymatic reagent were added.

The concentrations were determined against external calibration from 0 to $1 \mathrm{~g} / \mathrm{l}$ for citric and malic acids, from 0 to $2 \mathrm{~g} / 1$ for fructose and glucose and from 0 to $4 \mathrm{~g} / \mathrm{l}$ for sucrose.

\section{Results}

\subsection{Thermal degradation}

In spinach, for each temperature, the folate concentration decreased over time, with the appearance of a plateau at $120 \mathrm{~min}$ at $45^{\circ} \mathrm{C}, 60 \mathrm{~min}$ at $65^{\circ} \mathrm{C}$ and $30 \mathrm{~min}$ at $85^{\circ} \mathrm{C}$ (Fig. 1). However, this decrease was not monotonous, and concentration increased particularly between 10 and $20 \mathrm{~min}$ at $45^{\circ} \mathrm{C}$. For each temperature, the difference in concentrations between the two batches was relatively low. For all temperatures, degradation of the folates under study was not complete, and a plateau was reached with a $C_{\infty} / C_{0}$ ratio of $40 \%$ at $45^{\circ} \mathrm{C}, 42 \%$ at $65^{\circ} \mathrm{C}$ and $48 \%$ at $85^{\circ} \mathrm{C}$.

In green beans, evolution of folate concentrations at $45^{\circ} \mathrm{C}$ showed an increase in the first $20 \mathrm{~min}$, which was more marked for batch 2 , followed by a decrease until reaching a plateau at $120 \mathrm{~min}$ (Fig. 1). At higher temperatures, the concentration decrease was monotonous, except at $60 \mathrm{~min}$, and $65^{\circ} \mathrm{C}$, for the two independent kinetics. This decrease reached a plateau at $90 \mathrm{~min}$ for the two batches at $65^{\circ} \mathrm{C}$ and at $20 \mathrm{~min}$ for the two batches at $85^{\circ} \mathrm{C}$. Variability between batches for each temperature was low. Overall, temperature accelerated folate degradation, the plateau being reached more rapidly at $85^{\circ} \mathrm{C}$ than at $65^{\circ} \mathrm{C}$ or $45^{\circ} \mathrm{C}$. However, folate degradation was not complete; the level of the $C_{\infty} / C_{0}$ ratio was $20 \%$ both at $45^{\circ} \mathrm{C}$ and $65^{\circ} \mathrm{C}$.

Folate thermal degradation kinetics were modeled using first order with partial conversion. However, this model was not satisfying at $45^{\circ} \mathrm{C}$, where the folate concentration increased in the first minutes of the kinetics.

\subsection{Folate losses during diffusion}

\subsubsection{Total folate}

Total folate concentration was determined in vegetables by HPLC with fluorimetric detection after precolumn derivatization, and expressed as $5-\mathrm{CH}_{3}-\mathrm{H}_{4}$ folate in $\mathrm{mg} / \mathrm{kg}$ of fresh weight.

For spinach, the folate concentration at the beginning of the experiments, for both $\mathrm{pH}$ and the three temperatures studied, varied slightly between different batches. In all conditions, the folate concentration first decreased rapidly over time. This decrease was exponential until reaching a plateau after $60 \mathrm{~min}$ (data not shown). In green beans, the folate concentration at the beginning of the diffusion time course was the same (about $0.2 \mathrm{mg} / \mathrm{kg}$ expressed in fresh material) for both $\mathrm{pH}$ and temperatures studied. The decrease in folate concentration was much more dependent on temperature. Thus, at $\mathrm{pH} 5$ and $25^{\circ} \mathrm{C}$ the folate content was almost stable. However, it decreased at $45^{\circ} \mathrm{C}$ and more markedly at $65^{\circ} \mathrm{C}$. Folate decrease appeared to be exponential until reaching a plateau at $120 \mathrm{~min}$, at least at $65^{\circ} \mathrm{C}$ (data not shown).

The decrease in folate was faster for spinach than for green beans at the beginning of the time course. The plateau was also reached faster for spinach than for green beans with a higher level for green beans than for spinach. Indeed, the residual ratio in spinach (Table 1 ), expressed by the $C_{\infty} / C_{0}$ ratio at the plateau, was (on average) $26 \%$ of the initial concentration at $\mathrm{pH} 7$ and in the same order of magnitude at $\mathrm{pH} 5$. At $\mathrm{pH} \mathrm{7,} \mathrm{temperature} \mathrm{had} \mathrm{no} \mathrm{effect}$ on residual ratio while at $\mathrm{pH} 5$ temperature had an effect especially at $65{ }^{\circ} \mathrm{C}$. For green beans, the residual ratios $\left(C_{\infty} / C_{0}\right)$ were on average $62 \%$ of the initial concentration at $\mathrm{pH} 7$ and $72 \%$ of the initial concentration at $\mathrm{pH} 5$ (Table 1). Temperature seemed to have an effect on the residual ratio both at $\mathrm{pH} 7$ (from 0.7 at $25^{\circ} \mathrm{C}$ to 0.41 at $65^{\circ} \mathrm{C}$ ) and at $\mathrm{pH} 5$ (from 1.17 at $25^{\circ} \mathrm{C}$ to 0.43 at $65^{\circ} \mathrm{C}$ ).

Finally, the folate residual ratios $\left(C_{\infty} / C_{0}\right)$ were lower than those observed during the thermal degradation studies $\left(40 \%\right.$ at $45{ }^{\circ} \mathrm{C}$ and $42 \%$ at $65{ }^{\circ} \mathrm{C}$ ), for spinach at $\mathrm{pH}$ 5. For green beans, these residual ratios were higher than those observed in thermal degradation at pH $5\left(20 \%\right.$ at $45^{\circ} \mathrm{C}$ and $\left.65^{\circ} \mathrm{C}\right)$, the $\mathrm{pH}$ corresponding to that of spinach and green beans purees used during thermal degradation kinetics.

\subsubsection{Folate derivatives}

Concentrations of folate derivatives (in $\mathrm{mg} / \mathrm{kg}$ as fresh weight), in the initial sample and in the final sample of the diffusion kinetic studies were determined by stable isotope dilution assays. Results are presented in Table 2 for spinach and Table 3 for green beans.

Both in spinach and green beans, the main compound was $5-\mathrm{CH}_{3}-\mathrm{H}_{4}$ folate which represented about $70 \%$ of folates at the beginning of diffusion and also revealed the highest loss of all derivatives during diffusion. At $\mathrm{pH} 7,5-\mathrm{CH}_{3}-\mathrm{H}_{4}$ folate residual ratios $\left(C_{\infty} / C_{0}\right)$ in spinach decreased with increasing temperature. The same trend was observed with higher residual ratio $\left(C_{\infty} / C_{0}\right)$ at $\mathrm{pH}$ 5. For green beans, $5-\mathrm{CH}_{3}-\mathrm{H}_{4}$ folate residual ratio $\left(C_{\infty} / C_{0}\right)$ decreased with temperature increase at $\mathrm{pH} 7$ and $\mathrm{pH} 5$.

The second main class of folates derivatives was formyl derivatives. $10-\mathrm{HCO}-\mathrm{PteGlu}$ and $5-\mathrm{HCO}-\mathrm{H}_{4}$ folate represented $6 \%$ to $16 \%$ in spinach and $7 \%$ to $12 \%$ in green beans respectively. $5-\mathrm{HCO}-\mathrm{H}_{4}$ folate residual ratios $\left(C_{\infty} / C_{0}\right)$ increased with the temperature increase both in spinach and green beans between $\mathrm{pH} 7$ and $\mathrm{pH}$ 5. 10HCO-PteGlu residual ratios $\left(C_{\infty} / C_{0}\right)$ were quite stable at $25^{\circ} \mathrm{C}$ both at $\mathrm{pH} 7$ and 5 while it increased with rising temperature both at $\mathrm{pH}$ 7 and 5 .

Residual ratios $\left(C_{\infty} / C_{0}\right)$ of minor derivatives (PteGlu, $\mathrm{H}_{4}$ folate, $5,10-\mathrm{CH}^{+}-\mathrm{H}_{4}$ folate and $10-\mathrm{HCO}-\mathrm{H}_{2}$ folate) were very low and appeared quite variable during kinetics, both for spinach and green beans. 
Version définitive du manuscrit publiée dans / Final version of the manuscript published in :

Food Chemistry (2014),vol 157, p 439-447, DOI: 10.1016/j.foodchem.2014..02.054

Journal homepage: www.elsevier.com/locate/foodchem
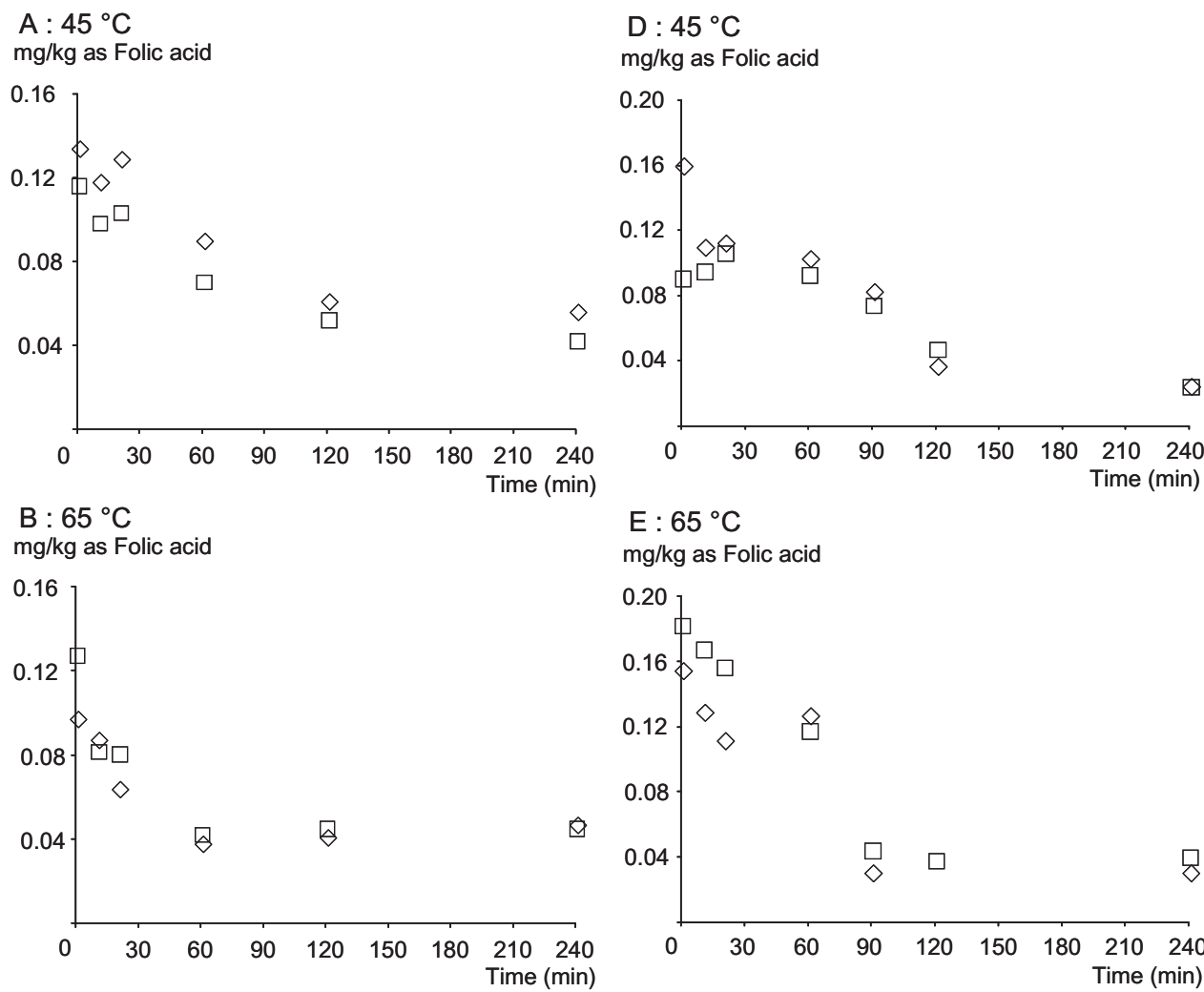

$\mathrm{E}: 65^{\circ} \mathrm{C}$

$\mathrm{mg} / \mathrm{kg}$ as Folic acid
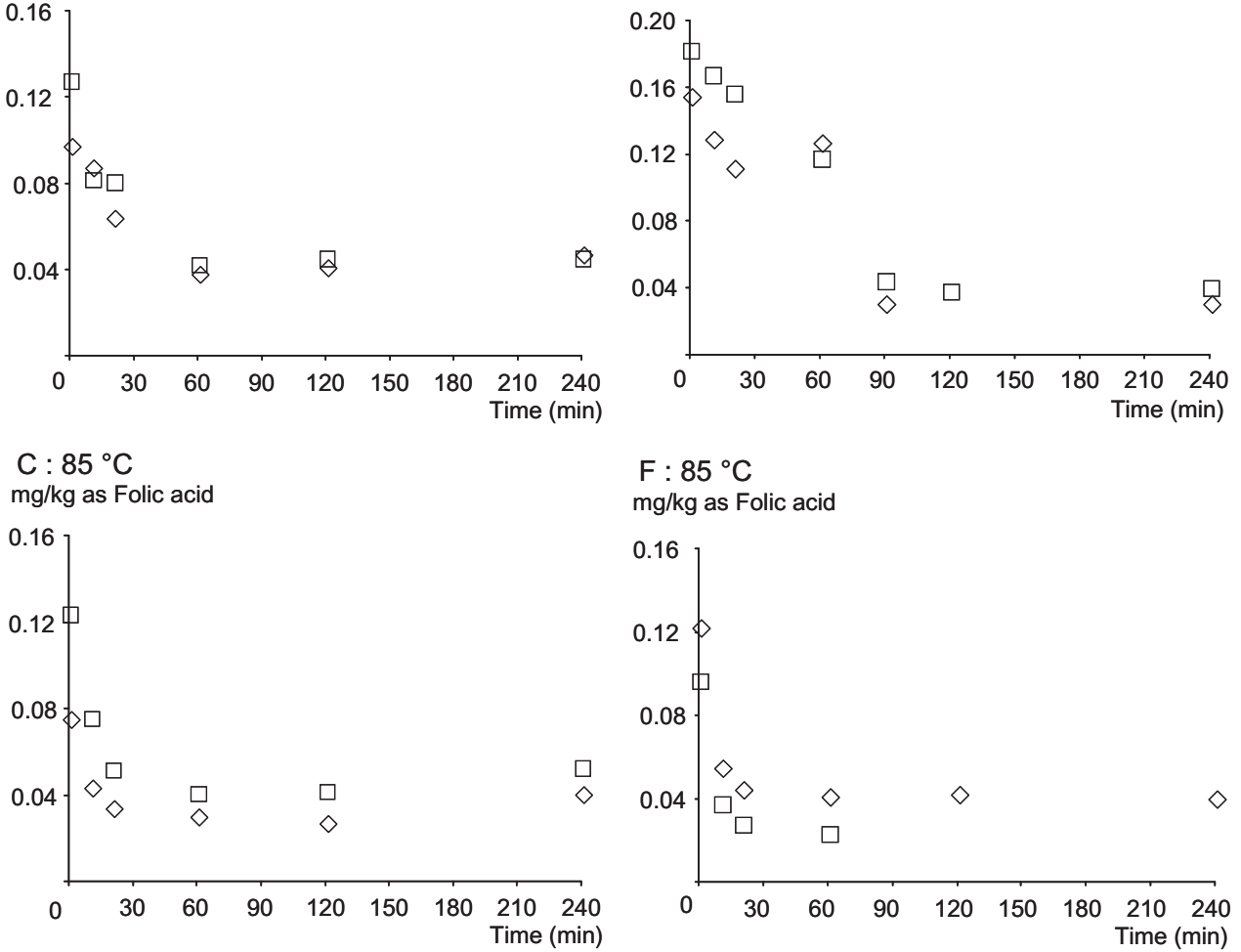

Fig. 1. Folates' thermal degradation in spinach and green beans purees. The left part of the graph represents the thermal degradation of total folates expressed as folic acid in $\mathrm{mg} / \mathrm{kg}$ of fresh weight at $45^{\circ} \mathrm{C}(\mathrm{A}), 65^{\circ} \mathrm{C}(\mathrm{B})$ and $85^{\circ} \mathrm{C}(\mathrm{C})$ in spinach under atmospheric oxygen conditions. The right part of the graph represents the thermal degradation of total folates ( $\mathrm{mg} / \mathrm{kg}$ of fresh weight) at $45^{\circ} \mathrm{C}(\mathrm{D}), 65^{\circ} \mathrm{C}(\mathrm{E})$ and $85^{\circ} \mathrm{C}(\mathrm{F})$ under atmospheric oxygen conditions in green beans. Empty lozenges correspond to data from batch 1 and empty squares represent data from batch 2 .

Finally, $C_{\infty} / C_{0}$ obtained by determining concentrations by HPLC with fluorimetric detection were globally higher than those obtained by the sum of concentrations of derivatives (as folic acid) by the stable dilution assay, especially at $65^{\circ} \mathrm{C}$ and $\mathrm{pH}$ 7. Analytical imprecision could be involved in this variation, especially by an over expression of concentrations resulting from the sample preparation for HPLC with fluorimetric detection.

\subsection{Diffusion modelling}

Modelling of experimental data was carried out according to Fick's second law for two reasons:

- Fick's second law is usually applied for describing of diffusion phenomena of water soluble compounds.
- The evolution of concentrations in the vegetables along the time course, with an exponential initial decrease followed by a plateau, corresponded to Fick's second law model both for plate (with an average thickness of spinach leaves of $2.74 \pm 0.8 \times 10^{-4} \mathrm{~m}$ ) and cylinder (with an average green beans diameter of $\left.6.66 \pm 1.36 \times 10^{-3} \mathrm{~m}\right)$.

The modeling was performed in the same way for all conditions of $\mathrm{pH}$ and temperature studied, both for folate, sugar and acid diffusion from spinach and green beans. An example is presented in Fig. 2, diffusion of folates for spinach at $\mathrm{pH} 7$ and $45^{\circ} \mathrm{C}(\mathrm{A})$ and for green beans at $\mathrm{pH} 7$ and $65^{\circ} \mathrm{C}(\mathrm{B})$, where lozenges represent experimental data and the line represents the diffusion model.

Model fitting was satisfactory both for spinach and green beans where the exponential shape curve was in accordance with 
Version définitive du manuscrit publiée dans / Final version of the manuscript published in :

Food Chemistry (2014),vol 157, p 439-447, DOI: 10.1016/j.foodchem.2014..02.054

Journal homepage: www.elsevier.com/locate/foodchem

Table 1

Diffusivity and $C_{\infty} / C_{0}$ of folates, sugars and acids in spinach and green beans.

\begin{tabular}{|c|c|c|c|c|c|c|c|c|c|c|c|c|c|c|}
\hline & \multirow[t]{2}{*}{$\mathrm{pH}$} & \multirow{2}{*}{$\begin{array}{l}\theta \\
\left({ }^{\circ} \mathrm{C}\right)\end{array}$} & \multicolumn{2}{|l|}{ Folates } & \multicolumn{2}{|l|}{ Glucose } & \multicolumn{2}{|l|}{ Fructose } & \multicolumn{2}{|l|}{ Sucrose } & \multicolumn{2}{|l|}{ Malic acid } & \multicolumn{2}{|l|}{ Citric acid } \\
\hline & & & $D$ & $C_{\infty} / C_{0}$ & $D$ & $\begin{array}{l}C_{\infty} / \\
C_{0}\end{array}$ & $D$ & $\begin{array}{l}C_{\infty} / \\
C_{0}\end{array}$ & $D$ & $\begin{array}{l}C_{\infty} / \\
C_{0}\end{array}$ & $\mathrm{D}$ & $\begin{array}{l}C_{\infty} / \\
C_{0}\end{array}$ & $\mathrm{D}$ & $\begin{array}{l}C_{\infty} / \\
C_{0}\end{array}$ \\
\hline \multirow[t]{7}{*}{ Spinach } & \multirow[t]{4}{*}{7} & 25 & $7 \pm 2.1 \times 10^{-12}$ & $0.28 \pm 0.07$ & $3.0 \times 10^{-12}$ & 0.50 & $\varnothing$ & $\varnothing$ & $\varnothing$ & $\varnothing$ & $3.5 \times 10^{-12}$ & 0.49 & $\varnothing$ & $\varnothing$ \\
\hline & & 45 & $7 \pm 1.7 \times 10^{-12}$ & $0.23 \pm 0.03$ & $1.0 \times 10^{-11}$ & 0.30 & $\emptyset$ & $\varnothing$ & $\emptyset$ & $\varnothing$ & $6.0 \times 10^{-12}$ & 0.19 & $\varnothing$ & $\varnothing$ \\
\hline & & 65 & $6 \pm 1.1 \times 10^{-12}$ & $0.28 \pm 0.12$ & $\varnothing$ & 0.86 & $\varnothing$ & $\varnothing$ & $\emptyset$ & $\varnothing$ & $2.5 \times 10^{-11}$ & 0.52 & $\varnothing$ & $\emptyset$ \\
\hline & & & & & & & $\varnothing$ & $\varnothing$ & $\varnothing$ & $\varnothing$ & & & $\varnothing$ & $\varnothing$ \\
\hline & \multirow[t]{3}{*}{5} & 25 & $6 \pm 2.1 \times 10^{-12}$ & $0.33 \pm 0.01$ & $6.0 \times 10^{-12}$ & 0.54 & $\varnothing$ & $\varnothing$ & $\emptyset$ & $\varnothing$ & $3.5 \times 10^{-12}$ & 0.57 & $\varnothing$ & $\emptyset$ \\
\hline & & 45 & $9 \times 10^{-12^{*}}$ & $0.38 \pm 0.14$ & $8.0 \times 10^{-12}$ & 0.02 & $\varnothing$ & $\emptyset$ & $\emptyset$ & $\emptyset$ & $5.5 \times 10^{-12}$ & 0.55 & $\varnothing$ & $\emptyset$ \\
\hline & & 65 & $8 \pm 1.4 \times 10^{-12}$ & $0.12 \pm 0.04$ & $9.5 \times 10^{-12}$ & 0.27 & $\varnothing$ & $\varnothing$ & $\varnothing$ & $\varnothing$ & $2.5 \times 10^{-11}$ & 0.27 & $\emptyset$ & $\emptyset$ \\
\hline Green & \multirow[t]{3}{*}{7} & 25 & $7 \pm 1.1 \times 10^{-10}$ & $0.73 \pm 0.03$ & $3.0 \times 10^{-10}$ & 0.61 & $1.5 \times 10^{-10}$ & 0.57 & $1.0 \times 10^{-09}$ & 0.51 & $1.0 \times 10^{-09}$ & 0.87 & $9.0 \times 10^{-09}$ & 0.05 \\
\hline \multirow[t]{5}{*}{ Beans } & & 45 & $8 \pm 1.7 \times 10^{-10}$ & $0.70 \pm 0.06$ & $3.0 \times 10^{-10}$ & 0.52 & $1.5 \times 10^{-10}$ & 0.55 & $2.5 \times 10^{-10}$ & 0.51 & $5.0 \times 10^{-10}$ & 0.44 & $9.0 \times 10^{-09}$ & 0.06 \\
\hline & & 65 & $6 \pm 2.0 \times 10^{-10}$ & $0.41 \pm 0.04$ & $2.5 \times 10^{-10}$ & 0.39 & $6.0 \times 10^{-10}$ & 0.39 & $5.0 \times 10^{-09}$ & 0.63 & $2.5 \times 10^{-10}$ & 0.36 & $5.0 \times 10^{-09}$ & 0.03 \\
\hline & \multirow[t]{3}{*}{5} & 25 & $\varnothing$ & $1.17 \pm 0.21$ & $1.7 \times 10^{-10}$ & 0.71 & $3.0 \times 10^{-10}$ & 0.75 & $1.0 \times 10^{-07}$ & 0.61 & $5.0 \times 10^{-10}$ & 0.75 & $4.0 \times 10^{-09}$ & 0.07 \\
\hline & & 45 & $5 \pm 1.4 \times 10^{-10}$ & $0.59 \pm 0.08$ & $1.5 \times 10^{-10}$ & 0.48 & $2.1 \times 10^{-10}$ & 0.43 & $5.0 \times 10^{-10}$ & 0.44 & $3.5 \times 10^{-10}$ & 0.51 & $5.0 \times 10^{-09}$ & 0.06 \\
\hline & & 65 & $3 \times 10^{-10^{*}}$ & 0.43 & $1.5 \times 10^{-10}$ & 0.47 & $2.0 \times 10^{-10}$ & 0.38 & $5.0 \times 10^{-10}$ & 0.55 & $2.0 \times 10^{-10}$ & 0.48 & $5.0 \times 10^{-09}$ & 0.06 \\
\hline
\end{tabular}

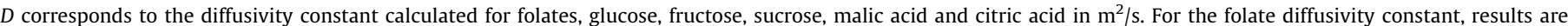
expressed as mean \pm standard deviation.

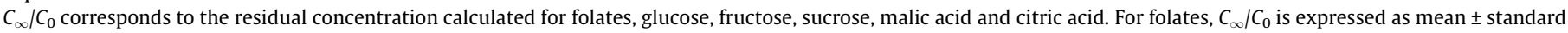
deviation.

Diffusivity constants for folates were calculated from concentrations expressed as $5-\mathrm{CH}_{3}-\mathrm{H}_{4}$ folate monoglutamate (after conversion of all derivatives).

$\theta$ Corresponds to the temperature in degree Celsius.

$\emptyset$ No data.

No standard deviation was calculated for those samples.

Table 2

Residual concentration $\left(C_{\infty} / C_{0}\right)$ of folate derivatives in spinach during diffusion kinetics.

\begin{tabular}{|c|c|c|c|c|c|c|c|c|c|c|}
\hline $\mathrm{pH}$ & $\theta$ & Time & 5- $\mathrm{CH}_{3}-\mathrm{H}_{4}$ folate & 5-HCO- $\mathrm{H}_{4}$ folate & 10-HCO-PteGlu & $\mathrm{H}_{4}$ folate & PteGlu & $5,10-\mathrm{CH}^{+}-\mathrm{H}_{4}$ folate & $10-\mathrm{HCO}-\mathrm{H}_{2}$ folate & Total folate (as folic acid) \\
\hline \multirow[t]{9}{*}{7} & \multirow[t]{3}{*}{25} & $t_{0}$ & 0.302 & 0.057 & 0.022 & 0.015 & 0.003 & 0.003 & 0.010 & 0.395 \\
\hline & & $t_{180}$ & 0.069 & 0.007 & 0.005 & 0.001 & 0.001 & 0.000 & 0.003 & 0.083 \\
\hline & & $C_{\infty} / C_{0}$ & 0.22 & 0.12 & 0.24 & 0.07 & 0.35 & 0.07 & 0.26 & 0.21 \\
\hline & \multirow[t]{3}{*}{45} & $t_{0}$ & 0.189 & 0.010 & 0.027 & 0.004 & 0.001 & 0.000 & 0.010 & 0.230 \\
\hline & & $t_{240}$ & 0.017 & 0.002 & 0.003 & 0.001 & 0.001 & 0.000 & 0.001 & 0.024 \\
\hline & & $C_{\infty} / C_{0}$ & 0.09 & 0.18 & 0.12 & 0.41 & 0.58 & 0.42 & 0.07 & 0.11 \\
\hline & \multirow[t]{3}{*}{65} & $t_{0}$ & 0.137 & 0.027 & 0.020 & 0.005 & 0.002 & 0.001 & 0.010 & 0.193 \\
\hline & & $t_{240}$ & 0.002 & 0.001 & 0.001 & 0.000 & 0.001 & 0.000 & 0.000 & 0.005 \\
\hline & & $C_{\infty} / C_{0}$ & 0.01 & 0.05 & 0.06 & $\emptyset$ & 0.31 & $\emptyset$ & $\emptyset$ & 0.03 \\
\hline \multirow[t]{9}{*}{5} & \multirow[t]{3}{*}{25} & $t_{0}$ & 0.280 & 0.064 & 0.013 & 0.012 & 0.002 & 0.002 & 0.003 & 0.361 \\
\hline & & $t_{240}$ & 0.102 & 0.056 & 0.011 & 0.004 & 0.002 & 0.002 & 0.003 & 0.171 \\
\hline & & $C_{\infty} / C_{0}$ & 0.36 & 0.86 & 0.86 & 0.33 & 0.76 & 0.85 & 0.86 & 0.48 \\
\hline & \multirow[t]{3}{*}{45} & $t_{0}$ & 0.344 & 0.109 & 0.008 & 0.039 & 0.002 & 0.003 & 0.002 & 0.484 \\
\hline & & $t_{240}$ & 0.051 & 0.045 & 0.008 & 0.002 & 0.002 & 0.000 & 0.002 & 0.105 \\
\hline & & $C_{\infty} / C_{0}$ & 0.14 & 0.41 & 1.08 & 0.05 & 0.81 & 0.02 & 1.24 & 0.22 \\
\hline & \multirow[t]{3}{*}{65} & $t_{0}$ & 0.350 & 0.126 & 0.009 & 0.035 & 0.003 & 0.003 & 0.003 & 0.506 \\
\hline & & $t_{240}$ & 0.002 & 0.036 & 0.013 & 0.002 & 0.001 & 0.000 & 0.001 & 0.052 \\
\hline & & $C_{\infty} / C_{0}$ & 0.007 & 0.28 & 1.41 & 0.05 & 0.48 & 0.01 & 0.41 & 0.10 \\
\hline
\end{tabular}

Results are expressed in $\mathrm{mg} / \mathrm{kg}$ of fresh weight, in blanched spinach $\left(t_{0}\right)$ and blanched spinach after diffusion $\left(t_{180}\right.$ or $\left.t_{240}\right)$.

$C_{\infty} / C_{0}$ is the ratio between the initial concentration and the final concentration.

$\theta$ Corresponds to the temperature in degree Celsius.

Significance of italic values correspond to the ration $C_{\infty} / C_{0}$.

experimental data (Fig. 2). In order to validate the model, correlation coefficients were maximized, both for spinach and green beans. The correlation coefficients considering folate diffusion were between 0.87 and 0.99 for spinach and between 0.77 and 0.99 for green beans. For sugars and acids, the correlation coefficients varied from 0.82 to 0.99 for spinach and from 0.93 to 0.99 for green beans.

The high level of the correlation coefficients and the correlation between experimental data and model show an adequacy between the model calculated and the phenomena observed both for folates, sugars and acids in spinach and green beans.

\subsubsection{Sugars and acids}

Acids and sugars are water-soluble molecules and stable at $\mathrm{pH} 5$ and 7 and temperatures from 25 to $65^{\circ} \mathrm{C}$, which were the conditions used in our study.
For spinach, only glucose and malic acid presented a sufficient initial concentration for relevant model fitting. Therefore, the diffusivity constant was calculated in spinach only for these two substances. The concentration of glucose and malic acid in spinach decreased until a plateau at about $60 \mathrm{~min}$. For both glucose and malic acid, temperature and $\mathrm{pH}$ did not have an effect on residual ratios.

For both $\mathrm{pH}$ and temperature the concentration of sugars decreased in green beans until reaching a plateau at about $120 \mathrm{~min}$. Plateau levels $\left(C_{\infty} / C_{0}\right)$ decreased with temperature at $\mathrm{pH} 7$, and between 25 and $45^{\circ} \mathrm{C}$ at $\mathrm{pH}$ 5, for glucose (Table 1). The residual ratio $\left(C_{\infty} / C_{0}\right)$ for fructose decreased with temperature both at $\mathrm{pH}$ 7 and 5 , while the sucrose residual ratio appeared stable. There was an effect of temperature on the reduction of the residual ratio $\left(C_{\infty} / C_{0}\right)$ of malic acid. In addition, it appeared that residual ratios $\left(C_{\infty} / C_{0}\right)$ of malic acid were higher at $\mathrm{pH} 5$ than at $\mathrm{pH} 7$ and at 45 and at $65^{\circ} \mathrm{C}$. 
Version définitive du manuscrit publiée dans / Final version of the manuscript published in :

Food Chemistry (2014),vol 157, p 439-447, DOI: 10.1016/j.foodchem.2014..02.054

Journal homepage: www.elsevier.com/locate/foodchem

Table 3

Folate derivatives concentration and $C_{\infty} / C_{0}$ ratios in green beans during diffusion kinetics.

\begin{tabular}{|c|c|c|c|c|c|c|c|c|c|c|}
\hline $\mathrm{pH}$ & $\theta$ & Time & 5- $\mathrm{CH}_{3}-\mathrm{H}_{4}$ folate & 5-HCO- $\mathrm{H}_{4}$ folate & 10-HCO-PteGlu & $\mathrm{H}_{4}$ folate & PteGlu & $5,10-\mathrm{CH}^{+}-\mathrm{H}_{4}$ folate & $10-\mathrm{HCO}-\mathrm{H}_{2}$ folate & Total folates (as folic acid) \\
\hline \multirow[t]{9}{*}{7} & \multirow[t]{3}{*}{25} & $t_{0}$ & 0.543 & 0.13 & 0.042 & 0.028 & 0.66 & 0.008 & 0.020 & 1.404 \\
\hline & & $t_{210}$ & 0.353 & 0.07 & 0.038 & 0.005 & 0.001 & 0.002 & 0.014 & 0.465 \\
\hline & & $C_{\infty} / C_{0}$ & 0.65 & 0.54 & 0.91 & 0.18 & 0.21 & 0.28 & 0.69 & 0.33 \\
\hline & \multirow[t]{3}{*}{45} & $t_{0}$ & 0.517 & 0.06 & 0.058 & 0.016 & 0.002 & 0.003 & 0.026 & 0.651 \\
\hline & & $t_{240}$ & 0.216 & 0.04 & 0.043 & 0.009 & 0.002 & 0.003 & 0.015 & 0.315 \\
\hline & & $C_{\infty} / C_{0}$ & 0.41 & 0.73 & 0.73 & 0.55 & 0.81 & 1.02 & 0.56 & 0.48 \\
\hline & \multirow[t]{3}{*}{65} & $t_{0}$ & 0.330 & 0.06 & 0.060 & 0.009 & 0.001 & 0.002 & 0.020 & 0.463 \\
\hline & & $t_{240}$ & 0.027 & 0.04 & 0.039 & 0.007 & 0.002 & 0.006 & 0.012 & 0.128 \\
\hline & & $C_{\infty} / C_{0}$ & 0.08 & 0.67 & 0.65 & 0.80 & 2.35 & 2.36 & 0.59 & 0.28 \\
\hline \multirow[t]{9}{*}{5} & \multirow[t]{3}{*}{25} & $t_{0}$ & 0.342 & 0.07 & 0.032 & 0.014 & 0.001 & 0.002 & 0.009 & 0.449 \\
\hline & & $t_{180}$ & 0.362 & 0.07 & 0.036 & 0.005 & 0.001 & 0.002 & 0.013 & 0.464 \\
\hline & & $C_{\infty} / C_{0}$ & 1.05 & 0.97 & 1.13 & 0.35 & 0.74 & 1.10 & 1.37 & 1.03 \\
\hline & \multirow[t]{3}{*}{45} & $t_{0}$ & 0.541 & 0.07 & 0.039 & 0.012 & 0.001 & 0.003 & 0.021 & 0.661 \\
\hline & & $t_{240}$ & 0.112 & 0.05 & 0.037 & 0.008 & 0.002 & 0.000 & 0.007 & 0.210 \\
\hline & & $C_{\infty} / C_{0}$ & 0.20 & 0.74 & 0.92 & 0.63 & 1.38 & 0.10 & 0.35 & 0.32 \\
\hline & \multirow[t]{3}{*}{65} & $t_{0}$ & 0.448 & 0.09 & 0.040 & 0.014 & 0.001 & 0.003 & 0.013 & 0.582 \\
\hline & & $t_{240}$ & 0.008 & 0.05 & 0.048 & 0.003 & 0.001 & 0.000 & 0.004 & 0.104 \\
\hline & & $C_{\infty} / C_{0}$ & 0.01 & 0.52 & 1.20 & 0.22 & 0.92 & 0.04 & 0.27 & 0.18 \\
\hline
\end{tabular}

Results are expressed in $\mathrm{mg} / \mathrm{kg}$ of fresh weight, in blanched green beans $\left(t_{0}\right)$ and blanched green beans after diffusion $\left(t_{180}\right.$ or $\left.t_{240}\right)$.

$C_{\infty} / C_{0}$ is the ratio between the initial concentration and the final concentration.

$\theta$ Corresponds to the temperature in degree Celsius.

Significance of italic values correspond to the ration $C_{\infty} / C_{0}$.
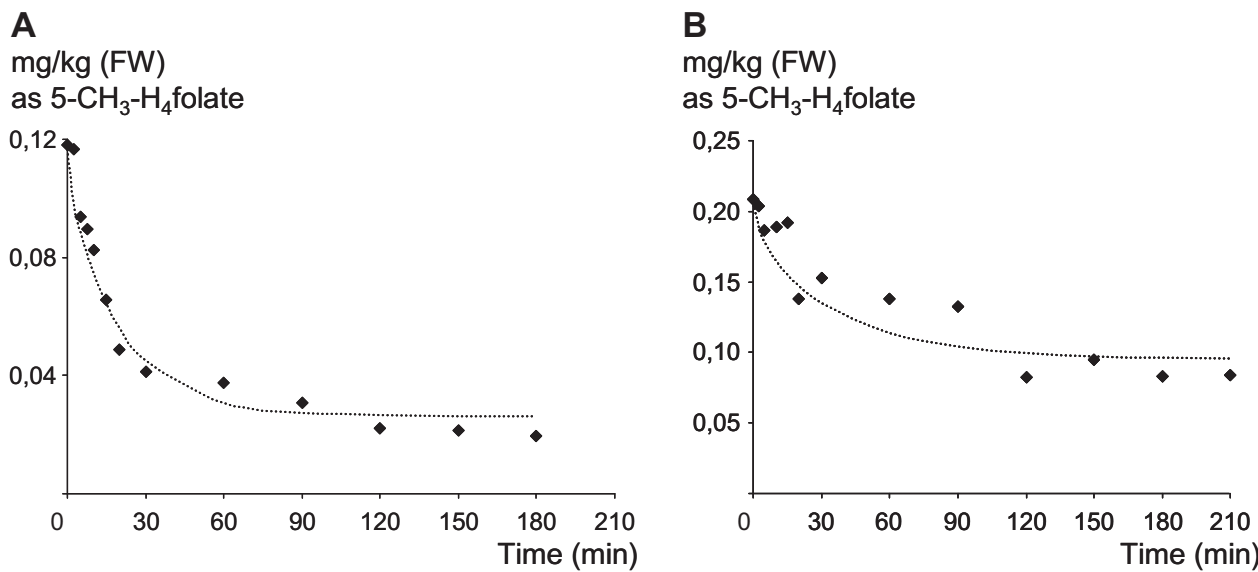

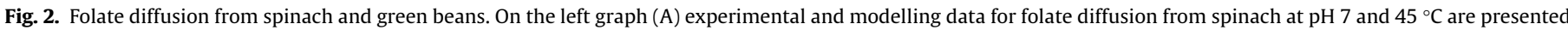

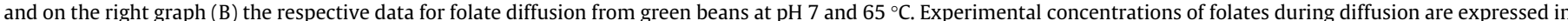

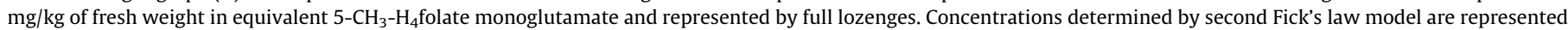
by the dotted line. Right graph (A).

For both spinach and green beans, diffusion of sugars and acids was determined as the mean of three batches for $\mathrm{pH} 7$ and two batches for $\mathrm{pH} 5$ for the three temperatures studied.

For spinach, the diffusivity constant determined was on average $5.5 \times 10^{-12} \mathrm{~m}^{2} / \mathrm{s}$ both for sugars and acids (Table 1 ). Glucose, fructose and sucrose from green beans showed a similar diffusivity constant, therefore only glucose, the most abundant compound, is presented. The temperature and $\mathrm{pH}$ did not seem to have any influence on the rate of diffusion of sugars in green beans, which was on average $6.1 \times 10^{-10} \mathrm{~m}^{2} / \mathrm{s}$.

Diffusion of acids (citric and malic acids) from green beans showed diffusivity constants in the same order for both acids at all temperatures and $\mathrm{pH}$, on average about $4.6 \times 10^{-10} \mathrm{~m}^{2} / \mathrm{s}(\mathrm{Ta}-$ ble 1). However, plateau levels were very different. Citric acid was almost completely extracted while malic acid was still present in green beans. The temperature and $\mathrm{pH}$ did not seem to have any effect on the rate of diffusion for the two acids studied. However, the diffusivity constant of citric acid was higher than that of malic acid and the diffusion was faster for citric acid than for malic acid.

\subsubsection{Folates}

Folate diffusion took place in the first $60 \mathrm{~min}$ for spinach and $120 \mathrm{~min}$ for green beans, until reaching a plateau after $60 \mathrm{~min}$ for spinach and $120 \mathrm{~min}$ for green beans. Correlation coefficients exceeded 0.9 both for spinach and green beans. Results are presented in Table 1.

Folate diffusivity constants averaged at $7.45 \times 10^{-12} \mathrm{~m}^{2} / \mathrm{s}$ for spinach and $5.86 \times 10^{-10} \mathrm{~m}^{2} / \mathrm{s}$ for green beans. For green beans, the folate diffusivity constant was hundred times higher than for spinach meaning that the diffusion of folates is faster for green beans than for spinach. For spinach, neither temperature nor $\mathrm{pH}$ had an effect on the folate diffusivity constant. For green beans, the folate diffusivity constant appeared variable between batches for the same conditions. Indeed, the low slope of folate concentration decrease did not allow distinguishing a significant effect of $\mathrm{pH}$ or temperature on the folate diffusivity constant.

The diffusivity constants calculated for folates both from spinach and green beans were in the same order of magnitude than those calculated for acids and sugars from the same matrix. 


\section{Discussion}

Our study was carried out at three temperatures (25, 45 and $65^{\circ} \mathrm{C}$ ), two of which were sufficient to allow thermal degradation of folates over the time scale used $\left(45\right.$ and $65^{\circ} \mathrm{C}$ ). For diffusion kinetics, incubation at $85^{\circ} \mathrm{C}$ proved to be impossible as the vegetables disintegrated over the time-course.

\subsection{Diffusion of water soluble compounds}

We could not follow folate, sugar and acid diffusion at $85^{\circ} \mathrm{C}$ because of the matrix instability at this temperature. Indeed, at $85^{\circ} \mathrm{C}$ for $4 \mathrm{~h}$, spinach and green beans would have been completely disintegrated.

Overall, little data is currently available concerning water soluble molecule diffusion from plant tissues. The few studies available concern acid and sugar diffusion.

Vukov and Monszpart Senyi (1977) have determined diffusivity constants of sugars and acids from apple slice to water at $75^{\circ} \mathrm{C}$ as $11.8 \times 10^{-10} \mathrm{~m}^{2} / \mathrm{s}$ for sugars and $14.2 \times 10^{-10} \mathrm{~m}^{2} / \mathrm{s}$ for acids.

Some experiments quantified diffusivity constants of glucose and sucrose from alginate gels to water, which are $2.55 \times 10^{-10}$ at $5^{\circ} \mathrm{C}$ for glucose and from $2.85 \times 10^{-10}$ to $4.13 \times 10^{-10} \mathrm{~m}^{2} / \mathrm{s}$ at 5 to $20^{\circ} \mathrm{C}$, for sucrose. From agar gels to water diffusivity constants are in the same range of magnitude at $2.47 \times 10^{-10} \mathrm{~m}^{2} / \mathrm{s}$ at $5{ }^{\circ} \mathrm{C}$ (Friedman \& Kraemer, 1930). Moreover, Schwartzberg and Chao (1982), determined diffusivity constants of glucose, fructose and sucrose to water at $25^{\circ} \mathrm{C}$ from $0.69 \times 10^{-9}$ to $0.54 \times 10^{-9} \mathrm{~m}^{2} / \mathrm{s}$.

Diffusivity constants calculated for acids and sugars in our study were in the range of $10^{-11} \mathrm{~m}^{2} / \mathrm{s}$ from spinach and $10^{-10} \mathrm{~m}^{2} / \mathrm{s}$ from green beans. From green beans, the constant we found is in agreement with those found in the literature for green beans (Friedman \& Kraemer, 1930; Schwartzberg \& Chao, 1982; Vukov \& Monszpart Senyi, 1977). In contrast, diffusivity constants for spinach calculated in our study are lower than those found in the literature. However, the diffusivity constants of sugars and acids were calculated from alginate, agar gels or apple slices. These matrixes are different from those we studied, particularly the physiological barriers such as the cuticles which could explain the difference observed for spinach. For folates, currently no data is available in literature. The diffusivity constant calculated for folates are in the same order of magnitude as those calculated for sugars and acids, with the same difference between the two matrices.

The system we have developed to study the diffusion of watersoluble molecules such as sugars, acids and folates from spinach and green beans appear to be efficient.

\subsection{Impact of $\mathrm{pH}$ and temperature}

Diffusivity constants calculated for folates from spinach and green beans, both at $\mathrm{pH} 7$ and $\mathrm{pH} 5$, were close to $10^{-12}$ and $10^{-}$ ${ }^{10} \mathrm{~m}^{2} / \mathrm{s}$ respectively, and similar to the constants calculated for sugars and acids for both vegetables and at both $\mathrm{pHs}$. The $\mathrm{pH}$ had no effect on folate, sugar and acid diffusion. At $\mathrm{pH} 5$ and $\mathrm{pH}$ 7 , the global negative electric charge of malic or citric acids, has the same polarity as that of cell walls. We can assume the existence of electrostatic repulsion between the cell walls and sugars and acids resulted in a limitation of diffusion. For green beans, a difference between the diffusivity constant of citric acid and malic acid of about a factor of ten was observed, although they are of similar size and charge in the conditions used. This difference could be due to the nature of the salts which neutralize citric acid, which have a greater ability to complex divalent cations. At pH 5 and $\mathrm{pH} 7$, the overall electrical charge of folates is also negative (Zhao, Matherly,
\& Goldman, 2009). Thus, it seems that the assumptions described for sugars and acids are transferable to folates, including the effects of electrostatic repulsion with cell walls. Moreover, folate interactions with macromolecules such as proteins could limit their diffusion under these $\mathrm{pH}$ conditions. Interaction between folates and proteins did not seem to be involved in our study because similar diffusivity constants were obtained for folates and sugars. The $\mathrm{pH}$ does not seem to be an important physico-chemical parameter for the diffusion of sugars, acids and folates.

Temperature did not have a significant effect on diffusion of water soluble compounds whatever matrix was considered, but had a significant effect on the residual ratio $\left(C_{\infty} / C_{0}\right)$ particularly for folates.

Residual levels of folates are lower for spinach (20\% at pH 7 and $10-30 \%$ at $\mathrm{pH} 5$ ) than for green beans $(40-70 \%$ at $\mathrm{pH} 7$ and $40-60 \%$ at $\mathrm{pH} 5$ ). This indicates that more folates are extracted from spinach than from green beans. Spinach and green beans represent two different tissues, consisting of a leaf and pod respectively. Spinach leaves are composed of two layers, each with only a few cell layers. In contrast, green beans are composed of pods and seeds parenchyma, which are two different histological structures. The existence of these different compartments and the possibility that folates are retained in these compartments by bondage to macromolecules would result in a lower residual ratio and a slower rate of diffusion. In beans, the existence of a compartmentalization of folates in the parenchyma and in the seeds is clearly established. This was verified here: folate concentration in the parenchyma was $0.252 \mathrm{mg} / \mathrm{kg}$ while it was three times higher in the seeds with a concentration of $0.709 \mathrm{mg} / \mathrm{kg}$.

\subsection{Folate thermal degradation}

Generally for each temperature, folate degradation kinetics were comparable in spinach and green beans. For all temperatures, a plateau was reached for both vegetables. The kinetics neither followed a first order nor a second order reaction, and a first order reaction with a partial conversion was still not satisfying, for the three temperatures and the two matrixes studied. This is in contradiction other studies where authors observed total folate degradation following a first order reaction (Mnkeni \& Beveridge, 1983; Oey, Verlinde, Hendrickx, \& Van Loey, 2006; Paine-Wilson \& Chen, 1979).

Two effects could explain this phenomenon: the predominant loss was due to oxidation during thermal degradation and the second one was due to evolution of each individual derivative and their degradation products during the kinetics. Moreover, folate concentrations in samples from thermal degradation were determined by HPLC with fluorimetric detection after derivatization. This could lead to an artifact as it involved conversion of all derivatives to $5-\mathrm{CH}_{3}-\mathrm{H}_{4}$ folate. It could also convert degradation products formed during the kinetics into $5-\mathrm{CH}_{3}-\mathrm{H}_{4}$ folate, which would lead to an overestimation of the folate residual ratio.

\subsection{Thermal degradation and industrial processing}

Folate degradation observed in industrial processes (Delchier et al., 2013) appear low compared to the model systems which could be explained by the difference between the time considered during the experiments ( $4 \mathrm{~h}$ ) and during processing (few minutes). Moreover, during sterilization of green beans, the can is a relatively small closed system, with less oxygen included than in our experiments. During this stage of the process, we observed a slight degradation of folates by about $10 \%$. Moreover, the treatment time is 6-15 min, and therefore relatively short. During blanching, the system behaves similarly to the kinetics of thermal degradation that 

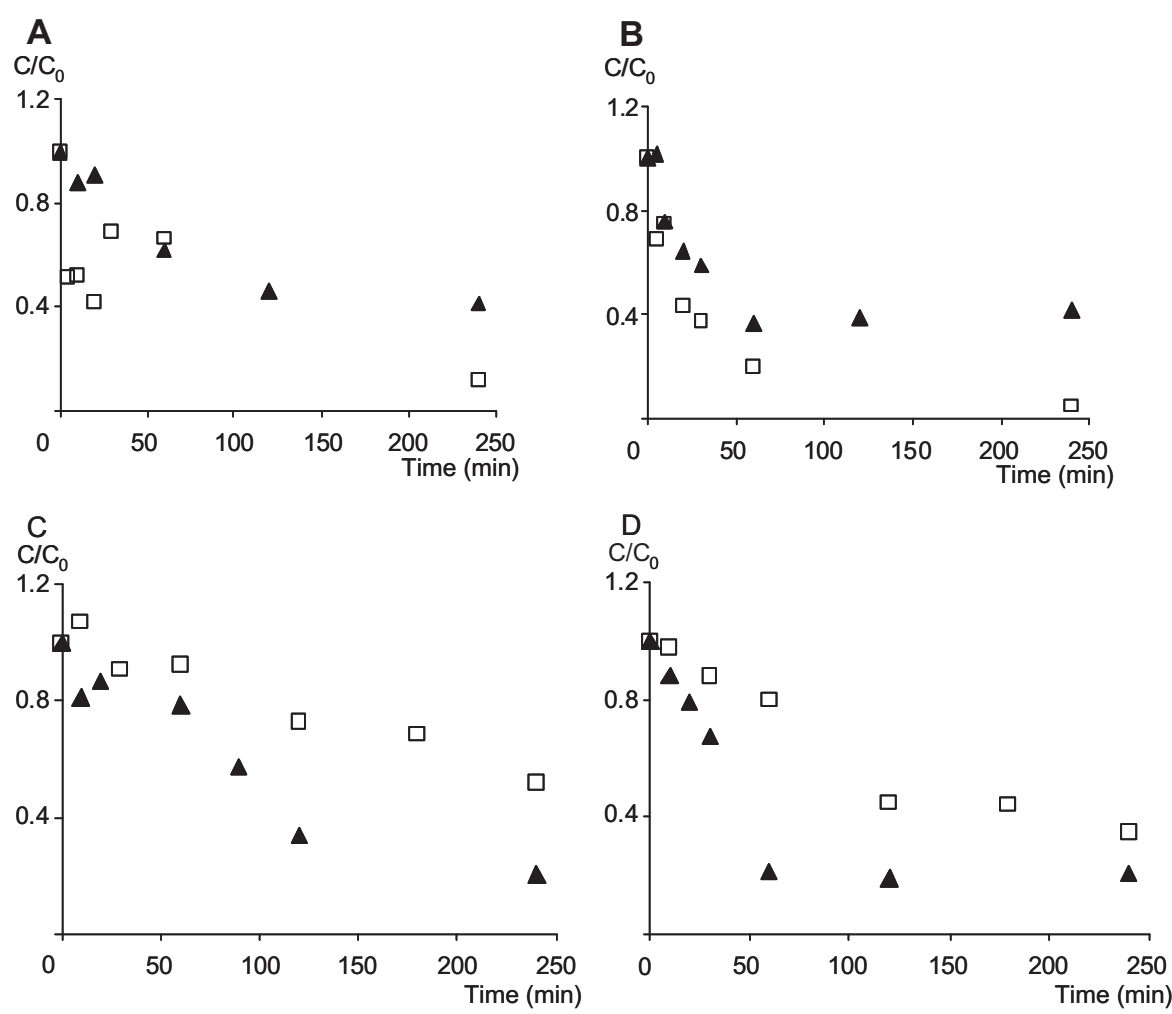

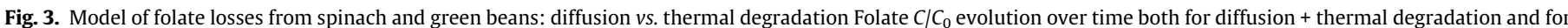

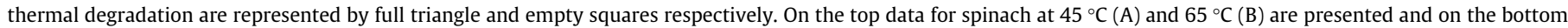
the respective data for green beans at $45^{\circ} \mathrm{C}(\mathrm{C})$ and $65^{\circ} \mathrm{C}(\mathrm{D})$.

we have performed here. During this stage, no losses of folates for both spinach and green beans were observed (Delchier et al., 2013). The blanching time applied in industrial processing is relatively short compared to those applied to the kinetics of thermal degradation (blanching of spinach: 70-120 s; green beans: 4$8 \mathrm{~min}$ ) (Delchier et al., 2013). Moreover, the high temperatures used correspond to very low solubilized oxygen content (Winkler, 1888).

Finally, the matrices entering the blanching step are not disrupted yet. Thus, the results observed during industrial blanching are relatively consistent with the conclusions of the kinetics of thermal degradation.

4.5. Integrative model: impact of thermal degradation during diffusion kinetics

The thermal degradation kinetics conducted under the same oxygen conditions as the diffusion kinetics show residual folate amounts slightly higher at the end of the thermal degradation kinetics for spinach (diffusion: 35\%, thermal degradation: 40\%) (Fig. 3). In contrast to this, in green beans, the residual ratio $\left(C_{\infty} / C_{0}\right)$, measured at the end of the diffusion kinetics, are higher than those measured at the end of the thermal degradation kinetics (diffusion: $59 \%$ at $45{ }^{\circ} \mathrm{C}$ and $43 \%$ at $65^{\circ} \mathrm{C}$; thermal degradation: $20 \%$ for both temperatures). In addition, residual ratios are obtained with very different compositions. So it seems that the relative share of losses by diffusion and thermal degradation vary according to the vitamers considered. Moreover, the thermal degradation kinetics were performed on purees obtained from ground vegetables in cans, where grinding could play a role, either by facilitating the access of oxygen into puree or by modifying the local environment.

\section{Conclusions}

Our study enabled us to determine folate diffusivity constants, using a novel and efficient experimental device where neither $\mathrm{pH}$ nor temperature had a significant effect on the diffusivity constant, in contrast to the significant effect of the two vegetables matrices. Evolution of vitamers during diffusion was dependent on their nature. 5- $\mathrm{CH}_{3}-\mathrm{H}_{4}$ folate and folic acid (PteGlu) were the two main derivatives lost during diffusion. These derivatives are more stable at $\mathrm{pH} 5$ than at $\mathrm{pH} 7$, so we can not exclude that these derivatives have been degraded over time, thus reducing the final concentration and inducing an increase in the total amount extracted. Evolution of derivatives during thermal degradation seems to be a key point for folate degradation by oxidation, which is why the next step of this study would be to determine the evolution of vitamers during oxidation in presence of different oxygen conditions.

By contrast, thermal degradation of folates in spinach and green beans was not monotonous especially at $45^{\circ} \mathrm{C}$ and kinetics modelling by a first order with partial conversion was not satisfying. Comparison between diffusion and thermal degradation showed that folates were more sensitive to thermal degradation for green beans, while for spinach diffusion mechanism appears to be predominant over thermal degradation.

\section{Acknowledgements}

This work benefited from financial support of ANR-09-ALIA-014 RIBENUT project: New approaches for microbial risk - nutritional benefits assessment in the case of heat processed vegetables. It was conducted as part of the UMT "Micronutriments des produits végétaux transformés" of ACTIA and with the financial support of the Ministère de l'Agriculture, de l'Alimentation, de la Pêche, de la Ruralité et de l'Aménagement du Territoire. 
Version définitive du manuscrit publiée dans / Final version of the manuscript published in :

Food Chemistry (2014),vol 157, p 439-447, DOI: 10.1016/j.foodchem.2014..02.054

Journal homepage: www.elsevier.com/locate/foodchem

The authors thank Caroline Garcia and Laura Badard for their excellent technical help.

\section{References}

ANSES: Apports Nutritionnels Conseillés en acide folique pour la population Française (2012). <http://www.anses.fr/Documents/ANC-Ft-TableauVitB9.pdf>.

Crank, J. (1975). The mathematics of diffusion (2nd ed.). New York: Oxford University Press.

Czeizel, A. E., \& Dudás, I. (1992). Prevention of the first occurrence of neural-tube defects by periconceptional vitamin supplementation. New England Journal of Medicine, 327(26), 1832-1835.

Delchier, N., Reich, M., \& Renard, C. M. G. C. (2012). Impact of cooking methods on folates, ascorbic acid and lutein in green beans (Phaseolus vulgaris) and spinach (Spinacea oleracea). LWT - Food Science and Technology, 49, 197-201.

Delchier, N., Ringling, C., Le Grandois, J., Aoudé-Werner, D., Galland, R., Georgé, S. et al. (2013). Effects of industrial processing on folate content in green vegetables. Food Chemistry, 139, 815-824.

DeSouza, S. C., \& Eitenmiller, R. R. (1986). Effects of processing and storage on the folate content of spinach and broccoli. Journal of Food Science, 51(3), 626-628.

Friedman, L., \& Kraemer, E. O. (1930). Diffusion of non electrolytes in gelatin gels. Journal of the American Chemical Society, 52, 1305.

Klein, B. P., Lee, H. C., Reynolds, P. A., \& Wangles, N. C. (1979). Folacin content of microwave and conventionally cooked frozen vegetables. Journal of Food Science, 44(1), 286-288.

Lafay, L. (2009). Etude Individuelle Nationale des Consommations Alimentaires 2(INCA-2). http://www.anses.fr/Documents/PASER-Ra-INCA2.pdf. (in french), uploaded January 2012.

McKillop, D. J., Pentieva, K., Daly, D., McPartlin, J. M., Hughes, J., Strain, J. J., et al. (2002). The effect of different cooking methods on folate retention in various foods that are amongst the major contributors to folate intake in the UK diet. British Journal of Nutrition, 88(06), 681-688.

Melse-Boonstra, A., Verhoef, P., Konings, E. J. M., van Dusseldorp, M., Matser, A., Hollman, P. C. H., et al. (2002). Influence of processing on total, monoglutamate and polyglutamate folate contents of leeks, cauliflower, and green beans. Journal of Agricultural and Food Chemistry, 50(12), 3473-3478.

Mnkeni, A. P., \& Beveridge, T. (1983). Thermal destruction of 5methyltetrahydrofolic acid in buffer and model food systems. Journal of Food Science, 48(2), 595-599.

Oey, I., Verlinde, P., Hendrickx, M., \& Van Loey, A. (2006). Temperature and pressure stability of L-ascorbic acid and/or [6s]5-methyltetrahydrofolic acid: A kinetic study. European Food Research and Technology, 223(1), 71-77.

Paine-Wilson, B., \& Chen, T. S. (1979). Thermal destruction of folacin: Effect of pH and buffer ions. Journal of Food Science, 44(3), 717-722.

Ringling, C., \& Rychlik, M. (2013). Analysis of seven folates in food by LC-MS/MS to improve accuracy of total folate data. European Food Research and Technology, 236, $17-28$.

Robinson, K. (2000). Homocysteine, B vitamins, and risk of cardiovascular disease. Heart, 83(2), 127-130.

Schwartzberg, H. G., \& Chao, R. Y. (1982). Solute diffusivities in leaching processes. Journal of Food Technology, 36, 74-77.

Snowdon, D. A., Tully, C. L., Smith, C. D., Riley, K. P., \& Markesbery, W. R. (2000). Serum folate and the severity of atrophy of the neocortex in Alzheimer disease: Findings from the Nun Study. The American Journal of Clinical Nutrition, 71(4), 993-998.

Vukov, K., \& Monszpart Senyi, J. (1977). Saftgewinnung aus Zuckerruben und Apfeln durch Gegenstromextraktion. Z. Zuckerind, 27(8).

Winkler, L. W. (1888). Die Bestimmung des im Wasser gelösten Sauerstoffen. Berichte der Deutschen Chemischen Gesellschaft, 21, 2843-2855.

Zhao, R., Matherly, L. H., \& Goldman, I. D. (2009). Membrane transporters and folate homeostasis: Intestinal absorption and transport into systemic compartments and tissues. Expert Reviews in Molecular Medicine, 11, 1-28. 